\title{
Analysis Of Current Ratio, Debt To Assets Ratio And Gross Profit Margin On Financial Distress With Moderated Share Prices In Retail Companies Listed In Securities Exchange
}

\author{
Deni Sunaryo \\ Faculty of Economics and Business, Serang Raya University \\ Corespondent Author \\ *Email: denisunaryomm@gmail.com
}

\begin{abstract}
.
This study aims to determine how much influence Current Ratio (CR), Debt to Asset Ratio (DAR) and Gross Profit Margin (GPM) on Financial Distress and moderated by Stock Prices. The population in this study were 24 companies in the retail subsector listed on the Southeast Asian Stock Exchange for the period 2012-2019. The method used is purposive sampling so that 15 companies that present complete financial reports according to the variables studied and obtained as many as 105 company samples were subjected to data outliers because the data did not have a normal distribution, thus 81 samples were obtained. The analysis technique used is multiple regression analysis and Moderated Regression Analysis (MRA). The results showed that the Debt to Asset Ratio (DAR) partially affected Financial Distress, while Current Ratio (CR) and Gross Profit Margin (GPM) partially had no significant effect on Financial Distress and simultaneously CR, DAR, GPM had an effect on Financial Distress. The moderation test shows that the stock price in this study is proven to moderate the relationship of the independent variables (CR, DAR and GPM) to the dependent variable (Financial Distress).
\end{abstract}

Keywords: Current Ratio (CR), Debt To Asset Ratio (DAR), Gross Profit Margin (GPM), Financial Distress and Stock Prices

\section{INTRODUCTION}

The retail or retail sub-sector company is a product marketing system in which sales transactions are directed to consumers. Economic sales growth since the Covid-19 pandemic phenomenon in early 2020 had an impact on sales growth in retail sub-sector companies in various Southeast Asian countries, this was due to the loss of people's purchasing power, spending patterns and people's mindsets caused by social restrictions large scale (PSBB) and lockdowns in various regions. The loss of purchasing power and decreasing public demand greatly affects the performance of retail companies and makes companies have to issue fixed cost components or expenses that must be paid. In the current situation, it is hoped that retail companies can change or create opportunities to continue running their business so that they do not get a negative impact or are in a decline in financial conditions and end in bankruptcy or liquidity and economic recession. Not only the negative impact of the Covid-19 pandemic, retail investors are now participating in supporting economic growth by investing their money, this is due to the relatively low benchmark interest rate in Indonesia and people who do not spend money on holidays, shopping, and others. 


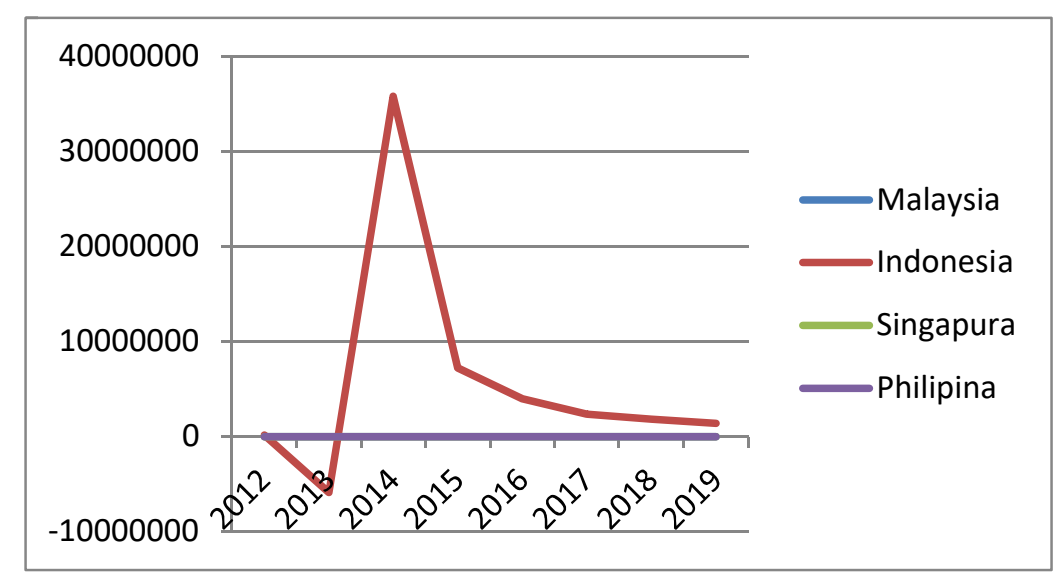

Figure 1. Financial Distress Data (Altman Z-Score) on Retail sub-sector companies in Southeast Asia for the period 2012-2019 (in currency units of each country)

In Figure 1 shows the lowest value of Financial Distress in Retail companies in Southeast Asia, namely 2013, while the highest Financial Distress is in 2014. Companies that have the lowest Financial Distress in 2012-2013 are LPPF companies, IN 2016, namely PRKN companies and in 2014, 2015, 2017, 2018 and 2016, namely the CMLT company. Meanwhile, the highest financial distress in 2012-2013 was a MIDI company, and in 2014-2019 it was an LPPF company.

The rise and fall of firm value as measured by the Altaman model analysis (Z-Score) is influenced by stock prices, earnings per share and sales. A good company's financial performance will allow the company to grow, this can increase investors' interest in investing because the company is believed to be able to manage its funds well. Altman analysis (Z-Score) is an interesting thing to study, seeing that the Z-Score analysis is used to predict the state of financial distress and the level of bankruptcy in retail companies in Southeast Asia. So from this description, to determine its effect on Financial Distress, it will be examined through an assessment of Current Ratio, Debt To Assets Ratio, Gross Profit Margin and moderated stock prices.

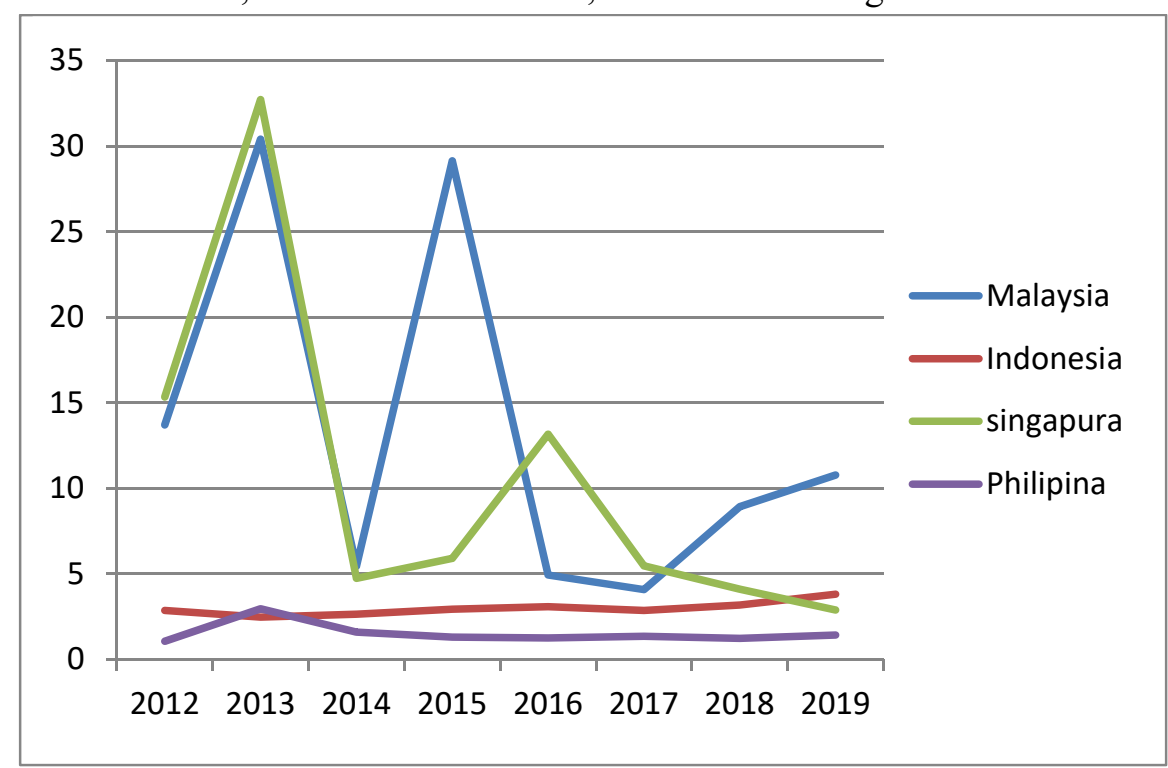

Figure 2. Current Ratio (CR) data for retail sub-sector companies in Southeast Asia for the period 2012-2019 (in the currency of each country)

Data is processed from several sources of stock exchanges in Southeast Asia using Microsoft Excel(2016)

Figure 2 shows the lowest Current Ratio (CR) value for retail companies in Southeast Asia, namely 2019, while the highest Current Ratio (CR) is in 2013. Companies that have the lowest Current Ratio (CR) in 2012, 2013 and 2016 are companies ARLC, in 2014-2017 namely the AEOM company, in 2015 namely the PRKN company and in 2018 - 2019 and namely the CMLT company. Meanwhile, the highest Current Ratio (CR) was in 2012-2013, namely PRKN companies, in 2014, 2015, 2017, 2018 and 2018, namely PDNI companies and in 2016, namely ZBRG companies. The company has the good ability to pay obligations 
that must be fulfilled with its current assets. It is a problem if the company does not have good liquidity capabilities, because liquidity is related to the ability of a company.

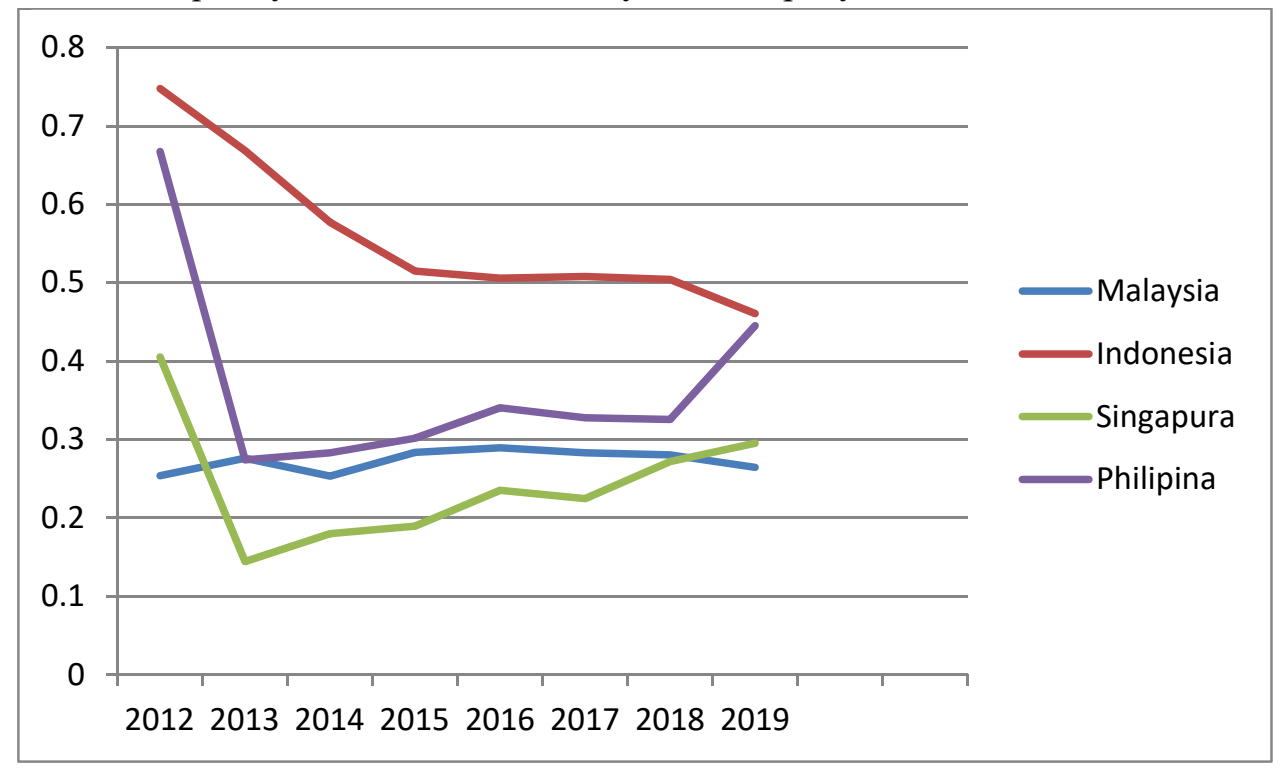

Figure 3. Debt To Assets Ratio (DAR) data in Retail sub-sector companies in Southeast Asia for the period 2012-2019 (in the currency of each country

Data is processed from several sources of stock exchanges in Southeast Asia using Microsoft Excel(2016) Figure 3 shows the lowest Debt To Assets Ratio (DAR) value for Retail companies in Southeast Asia, namely 2012-2016, while the highest Debt To Assets Ratio (DAR) is in 2012. Companies that have the lowest Debt To Assets Ratio (DAR) are 2012 - 2014, namely the PRKN company, in 2013-2018 namely the PRAL company and in 2018-2019 namely the PDNI company. Meanwhile, companies that had the highest Debt To Assets Ratio (DAR) in 2012-2014 were LPPF companies and in 2015-2019 MIDI companies.

The high and low value of a company's capital structure will affect the value of a company's financial performance, this is because the value of the capital structure as measured by the Debt To Assets Ratio (DAR) indicator is related to the debt management of a company.

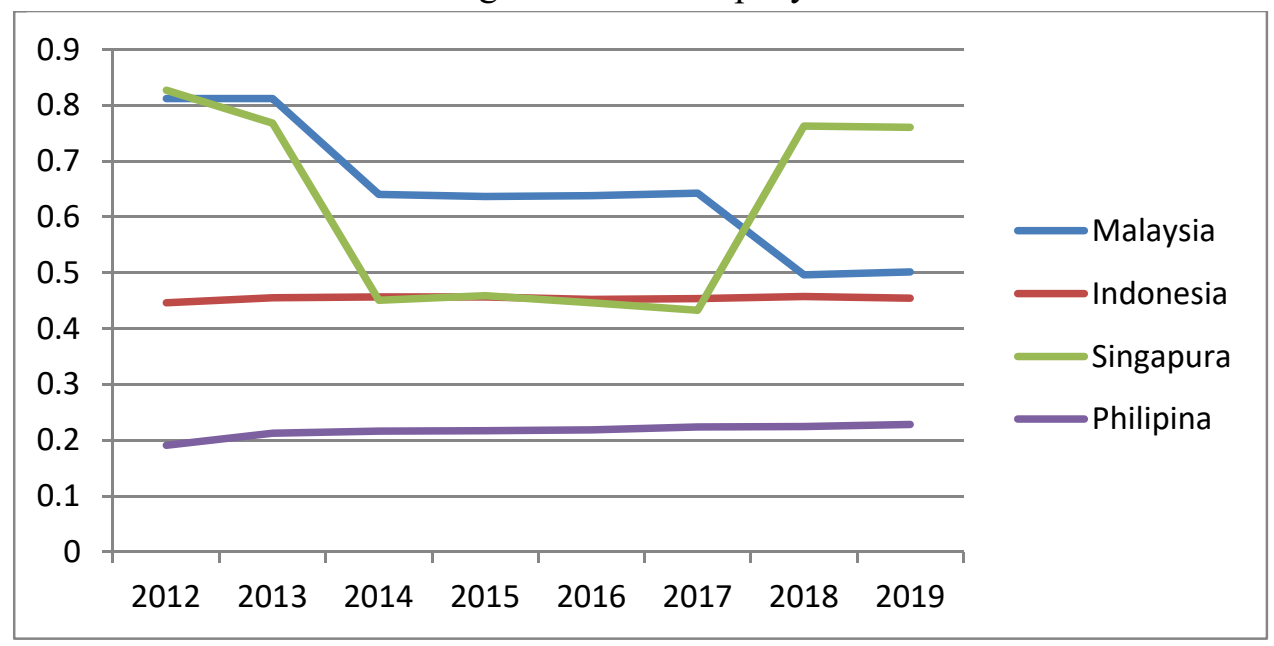

Figure 4. Gross Profit Margin (NPM) data on retail sub-sector companies in Southeast Asia for the period 2012-2019 (in the currency of each country)

Data is processed from several sources of stock exchanges in Southeast Asia using Microsoft Excel(2016)

Figure 4 shows the Gross Profit Margin (GPM) data for companies that experienced an increase in gross profit, namely AEOM in 2017-2019 and ALCP in 2016-2019. Several companies that experienced a decrease in gross profit were KMDA in 2014-2019. The Gross Profit Margin Ratio (GPM) is used to see the 
final result of a number of policies and decisions that have been taken by the company on its financial performance, so GPM is used as an indicator to see how much gross profit the company gets on its sales.

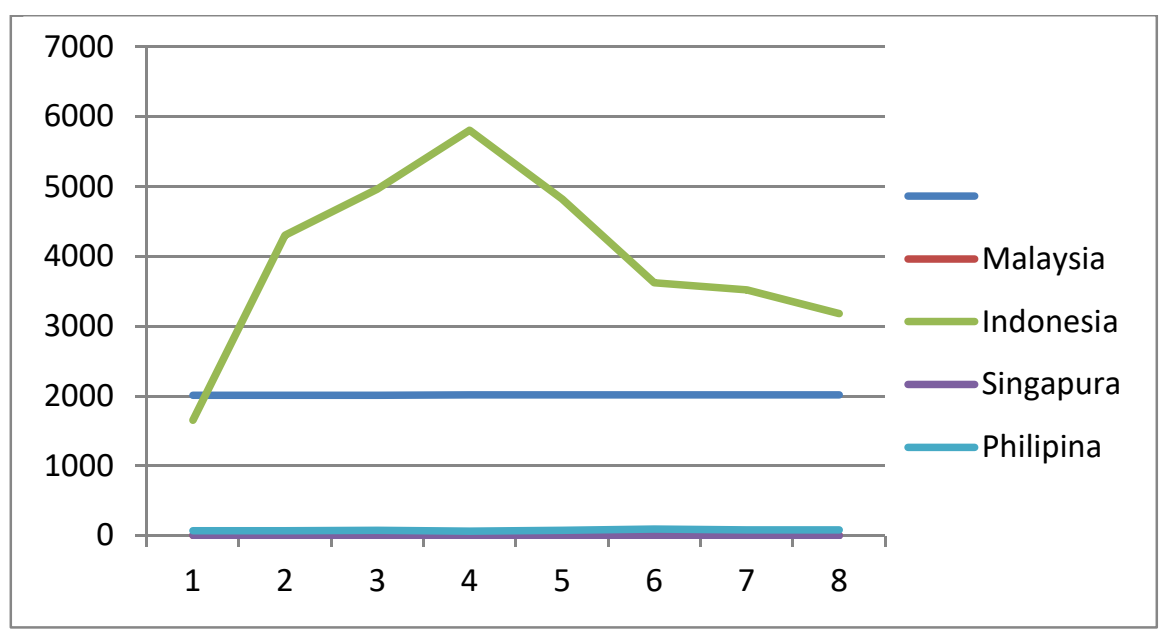

Figure 5. Stock Price Index data for retail sub-sector companies in Southeast Asia for the period 2012-2019 (in the currency of each country)

Data is processed from several sources of stock exchanges in Southeast Asia using Microsoft Excel(2016)

Figure 5 shows that the value of stock prices fluctuates at any time, this is influenced by the supply and demand that occurs between sellers and buyers of shares. Retail companies that experienced an increase in share prices, namely in 2015 and Retail companies that experienced a decrease in share prices, namely in 2019. Companies that experienced the highest increase in share prices in 2012-2018 were LPPF companies and in 2019, namely SONA companies. Meanwhile, companies that experienced a decline in share prices in 2012-2014 were POHK companies and in 2015-2019 were PRAL companies.

The increase and decrease in share prices are indicated by the performance of a company. Good company performance will affect the company's financial condition, it is necessary to analyze the factors that affect the ups and downs of stock prices, this is necessary for investors to see the company's ability to grow and develop in the future and achieve the goals to be achieved.

Based on research related to the current ratio, debt to assets ratio, gross profit margin, financial distress and stock prices have been carried out and there are mixed results. According to research by Justin Lord, Amy Landry, Grant T. Savage, Robert Weech-Maldonado states that liquidity, profitability and effectiveness have significant predictors of financial distress[1]. According to research by RochmanMarota, AsepAlipudin and AyursilaMaiyarash state that the debt to assets ratio partially and simultaneously has a significant influence in predicting financial stress, the current ratio partially and simultaneously has a significant influence in predicting financial distress[2].

According to research by CellySeptineMayliza, Adler HaymansManurung and Benny Hutahayan, the gross profit margin has a significant negative effect on the probability of bankruptcy, the current ratio has a significant negative effect on the probability of bankruptcy probability[3]. According to research by Zakiyuddien states that the current ratio has a positive and significant effect on financial distress while the debt ratio has a negative and significant effect on financial distress[4].

Based on the research of Carlos J. Rodríguez-Rad, F. Javier Rondán-Cataluña \& Juan Antonio MacíasMolina states that average total investment and average down payment costs have no effect on financial distress[5].According to research by TioNoviandri states that the current ratio has a positive and significant impact on financial distress[6]. According to research by RinaIndriani and HakimanThamrin, the current ratio and debt to assets ratio have a positive and significant effect on financial distress[7]. According to research by NazSayari and BisaSimgaMugan, states that financial ratios do not have a linear effect on financial distress[8].

Based on the research of AndiWawo\&Nirwana, it is stated that the financial distress has a significant negative effect on stock prices[9]. According to Mahruzal and Muammar Khaddafi, the gross profit margin 
does not have a significant effect on stock prices[10]. According to AdityaPratama and TeguhErawati, the current ratio has a positive and significant effect on stock prices[11]. According to the research of HaunanDamar, Umar Farouk and Winarto, stated that the current ratio has a negative effect and does not have a significant effect on stock prices[12]. According to research by RatnaAndira and Yahya, the current ratio has a negative and insignificant effect on stock prices[13]. According to research by JessySafitriSitorus, Funny, Cindy Marcella, Evelyn and JeannyGunawan, it is stated that the current ratio has a significant negative effect on stock prices[14].

Based on the research description above, the researcher is interested in conducting research with the title "Analysis of Current Ratio, Debit to Assets Ratio, Gross Profit Margin Against Financial Distress with Moderated Stock Prices in Retail Companies Listed on the Stock Exchange 2012-2019 Period".

\section{RESEARCHMETHODS}

This study aims to examine the effect, current ratio, and debt to asset ratio, gross profit margin on financial distress with stock prices as a moderating variable in retail sub-sector companies listed on the Southeast Asian stock exchange for the period 2012-2019. Types of data used in this study is quantitative data and is secondary data, obtained from food and beverage sub-sector companies listed on the Southeast Asian Stock Exchange (BEI, SGX, PSE and MYX). This research will use quantitative methods. Quantitative methods are called traditional methods, because this method has been used for a long time so that it has become a traditional method for research.

\section{Population and Sample}

The population used in this study is the financial statements of 24 companies in the Retail sub-sector in Southeast Asia. The samples used in this study were 15 companies with complete financial reports from the 2012-2019 research year.

Table 1. List of Retail Sub-Sector Companies in Southeast Asia for the study sample for the period $2012-2019$

\begin{tabular}{|c|c|c|c|}
\hline No. & $\begin{array}{c}\text { Southeast Asian } \\
\text { country }\end{array}$ & $\begin{array}{l}\text { Company } \\
\text { Code }\end{array}$ & Company \\
\hline 1 & \multirow{6}{*}{ Malaysia } & AEOM & Aeon Co Bhd \\
\hline 2 & & ATLC & Atlanticus Holdings Corporation \\
\hline 3 & & HAIO & Hai-O Enterprise Bhd \\
\hline 4 & & PDNI & Padini Holdings Bhd \\
\hline 5 & & PRKN & Parkson Holdings Bhd \\
\hline 6 & & POHK & Poh Kong Holdings Bhd \\
\hline 7 & \multirow{4}{*}{ Indonesia } & ACES & Ace Hardware Indonesia Tbk \\
\hline 8 & & MIDI & Midi Utama Indonesia Tbk \\
\hline 9 & & SONA & Sona Topas Tourism Industry \\
\hline 10 & & LPPF & Matahari Department Store Tbk \\
\hline 11 & \multirow{3}{*}{ Singapura } & CMLT & Capitaland Mall Trust \\
\hline 12 & & ZBRG & Zhonngmin Baihul Retail Gruop Ltd \\
\hline 13 & & PRAL & Parkson Retail Asia Ltd \\
\hline 14 & \multirow{2}{*}{ Filipina } & RRHI & Robinsons Retail Holdings Inc \\
\hline 15 & & ALCO & ArthaLand Corp \\
\hline
\end{tabular}

\section{DISCUSSION}

\section{Descriptive Statistics of Research Variables}

Table 2 Descriptive Statistics of Research Variables

\begin{tabular}{|c|c|c|c|c|c|}
\hline \multicolumn{6}{|c|}{ Descriptive Statistics } \\
\hline & $\mathbf{N}$ & Minimum & Maximum & Mean & Std. Deviation \\
\hline Current Ratio $\times 1)$ & 112 & .02 & 169,13 & 8,9654 & 24.73018 \\
\hline Debt to Asset Ratio (12) & 112 & .00 & 1,66 &, 3555 & .29366 \\
\hline Gross Profit Margin $\times 3$ ) & 112 &, 00 & 1,00 & .5541 & 34477 \\
\hline Financial Distress m & 112 & $-2,53$ & 27,00 & 4,2016 & 3,86082 \\
\hline Harga Saham $(Z)$ & 112 & 01 & 17125,00 & 1145,5443 & 3043,77724 \\
\hline Valid (IIstwise) & 112 & & & & \\
\hline
\end{tabular}

Source: Results of data processing for SPSS V21 
Based on the results of statistical analysis, it shows that:

a. During 2012 to 2019 the minimum value of the Current Ratio (CR) variable was 0.02 , the maximum Current Ratio (CR) value was 169.13. The mean value of Current Ratio (CR) is 8.9654 and the standard deviation value is 24.73018 with 112 observation data.

b. During 2012 to 2019 the minimum value of the Debt to Asset Ratio (DAR) variable was 0.00, the maximum Debt to Asset Ratio (DAR) value was 1.66. The mean value of Debt to Asset Ratio (DAR) is 0.3555 and the standard deviation value is 0.29366 with 112 observation data.

c. During 2012 to 2019 the minimum value of the Gross Profit Margin (GPM) variable is 0.00 , the maximum Gross Profit Margin (GPM) value is 1.00, the mean Gross Profit Margin (GPM) value is 0.55421 and the standard deviation value is 0,34477 with 112 observation data.

d. During 2012 to 2019 the minimum value of the Financial Distress variable was -2.53 , the maximum Financial Distress value was 27.00, the mean Financial Distress value was 4.2016 and the standard deviation value was 3.86082 with 112 observation data.

e. During 2012 to 2019 the minimum value of the Stock Price variable was 0.01, the maximum value of the Share Price was 17125.00, the mean value of the Share Price was 1145.5443 and the standard deviation value was 3043.77724 with observation data of 112 .

\section{Classic assumption test}

\section{Normality test}

Table 3 Normality Test

One Sample Kolgomorov Smirnov (Before Outlier)

One-Sample Kolmogorov-Smirnov Test

\begin{tabular}{|c|c|c|}
\hline & & $\begin{array}{l}\text { Unstandardiz } \\
\text { ed Residual }\end{array}$ \\
\hline $\mathrm{N}$ & & 112 \\
\hline \multirow[t]{2}{*}{ Normal Parameters ${ }^{a, b}$} & Mean &, 0000000 \\
\hline & Std. Deviation & 3,81022723 \\
\hline \multirow[t]{3}{*}{ Most Extreme Differences } & Absolute &, 123 \\
\hline & Positive &, 113 \\
\hline & Negative &,- 123 \\
\hline Kolmogorov-Smirnov Z & & 1,300 \\
\hline Asymp. Sig. (2-tailed) & &, 068 \\
\hline
\end{tabular}

Source: Results of data processing for SPSS V21

Figure 6 Test Histogram (Before Outlier)

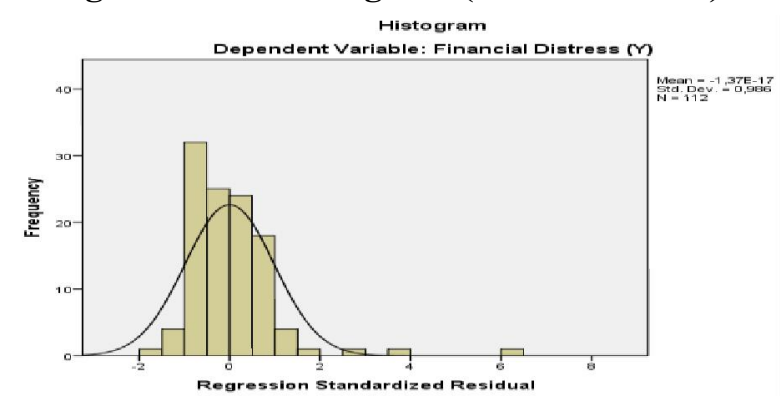

Figure 7 P-Plot Normality Test (Before Outlier)

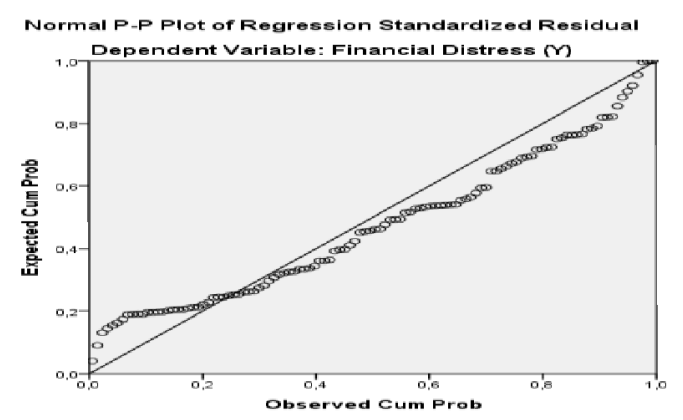


Source: Results of data processing for SPSS V21

From the one-sample KS normality test, it was found that the Asymp sig 2-tiled value was $0.068>$ 0.05 , which means that the data were normally distributed, but in the histogram and P-Plot graph normality test it can be concluded that the regression model does not meet the normality assumption, this shows that the test results The normality test with the histogram and P-plot graphs above shows that the unfulfilled normality test is seen from the graph that does not form a bell and is more inclined to the left which does not follow the diagonal line and then on the P-Plot graph the points appear not to follow and away diagonal line. Because the data is not normally distributed, data outliers or data deletions are carried out, with the initial $\mathrm{N}$ amounting to 112 to 81 then the second stage of normality test is carried out as follows:

Table 4 Normality Test

One Sample Kolmogorov Smirnov (After Outlier)

One-Sample Kolmogorov-Smirnov Test

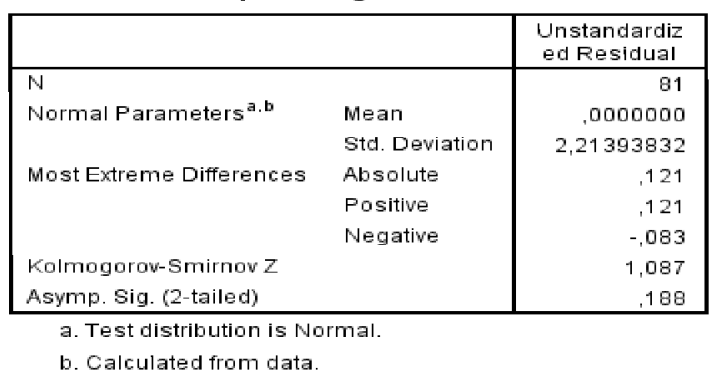

Source: Results of data processing for SPSS V21

Figure 8 Test Histogram (After Outlier)

Histogram

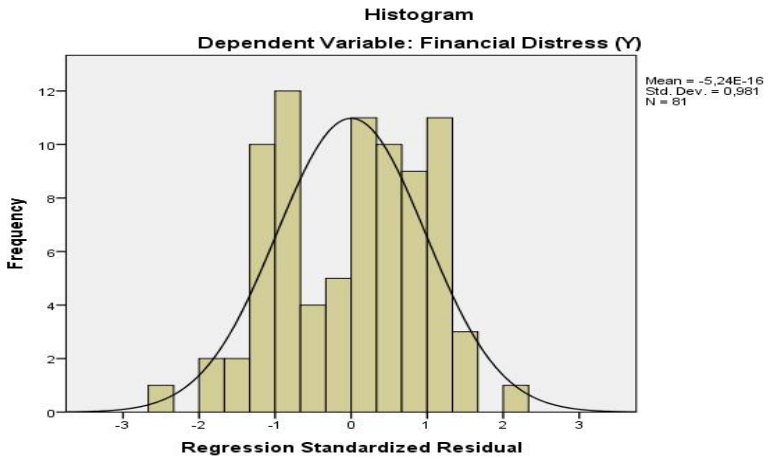

Source: Results of data processing for SPSS V21

Figure 8 P-Plot Normality Test (After Outlier)

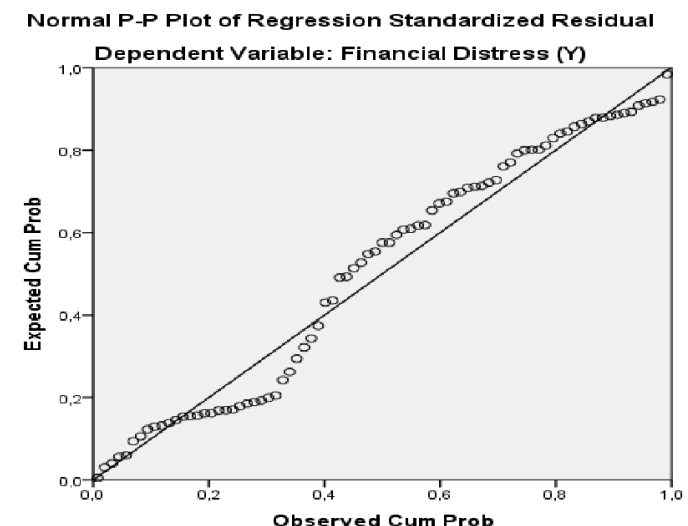

Source: Results of data processing for SPSS V21

In the second stage of testing, the results obtained from the normality test of one sample Kolgomorov Smirnov with an asymp sig value. (2-tilled) is $0.189>0.05$ and the normality test with the histogram and P-plot graphs above shows that the normality test is fulfilled, seen from the graph that forms a bell and follows the diagonal line and then on the P-Plot chart the points appear to follow and 
approaching the diagonal line means that the data is normally distributed.

\section{Multicollinearity Test}

Table 5 Multicollinearity Test

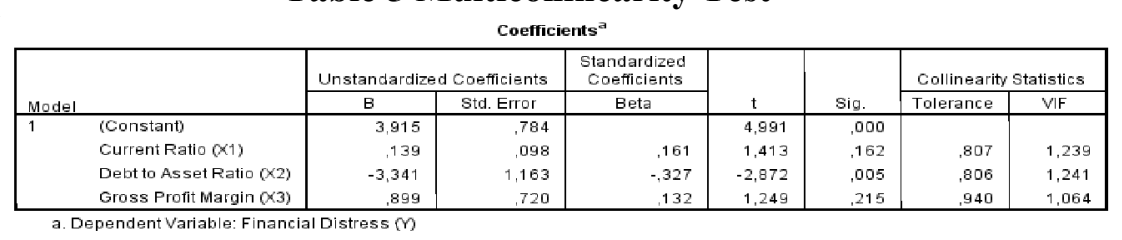

Source: Results of data processing for SPSS V21

From the multicollinearity test table, it can be concluded that the results are fulfilled because each variable has a tolerance value greater than 0.10 and a VIF value that is below $<10$.

\section{Heteroscedasticity Test}

Figure 9 Heteroscedasticity Test

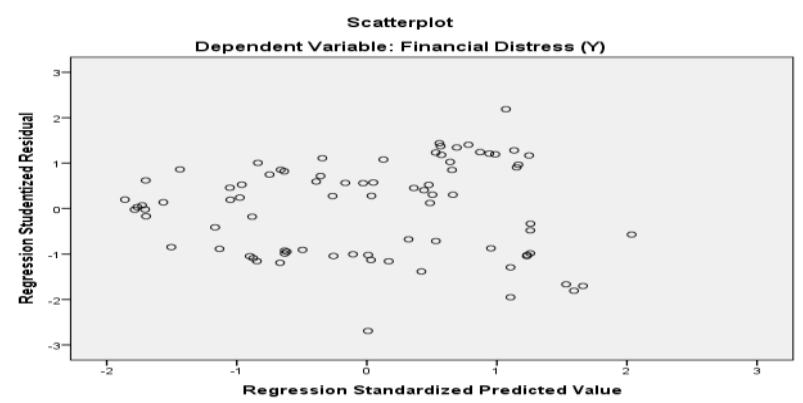

Source: Results of data processing for SPSS V21

From the heteroscedasticity test image shows that the data has spread below and above zero and does not form a pattern

\section{Autocorrelation Test}

\section{Table 6 Autocorrelation Test}

\begin{tabular}{|c|c|c|c|c|c|}
\hline \multicolumn{6}{|c|}{ Model Summary } \\
\hline Model & $\mathrm{R}$ & R Square & $\begin{array}{c}\text { Adjusted R } \\
\text { Square }\end{array}$ & $\begin{array}{l}\text { Std. Error of } \\
\text { the Estimate }\end{array}$ & $\begin{array}{l}\text { Durbin- } \\
\text { Watson }\end{array}$ \\
\hline 1 & $445^{a}$ & 198 & .166 & 2,25665 & 1,853 \\
\hline
\end{tabular}

\section{Source: Results of data processing for SPSS V21}

The autocorrelation test results show the durbine watson (DW) value of 1.853 which indicates that the DW value is between DU and 4-DU or $1.7164<1.853<2,2836$ The DW value is in an area where there is no autocorrelation or there is no autocorrelation symptom.

\section{Multiple Regression Analysis}

\section{Partial Significance Test (t-test)}

Table 7 Results of Multiple Regression Analysis and t-test

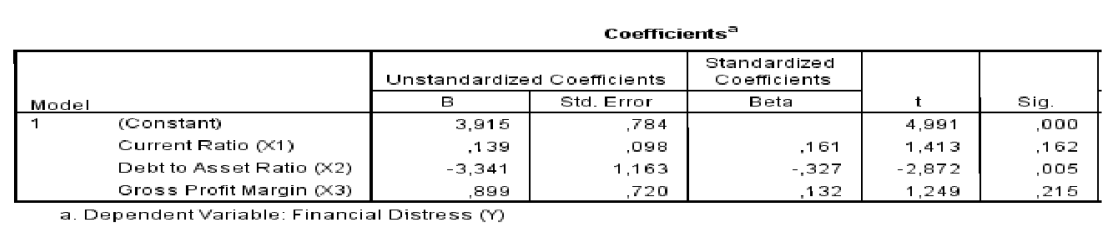

Source: Results of data processing for SPSS V21 
The $t$ test results show that the $t$ value is greater than the $t$ table in hypothesis $2(2.872>1.66388)$ and the significance value is less than $0.05(0.005<0.05)$ and in hypotheses 1 and 3 the $t$ value is smaller than the $t$ value table $(1.413$ and $1.249<1.66388)$ and the significance value is greater than $0.05(0.162$ and $0.215>0.05)$ This means that hypothesis 2 is accepted / supported while hypotheses 1 and 3 are not accepted / not supported.

\section{Partial Significance Test (F-Test)}

Table 8 F-Test Results

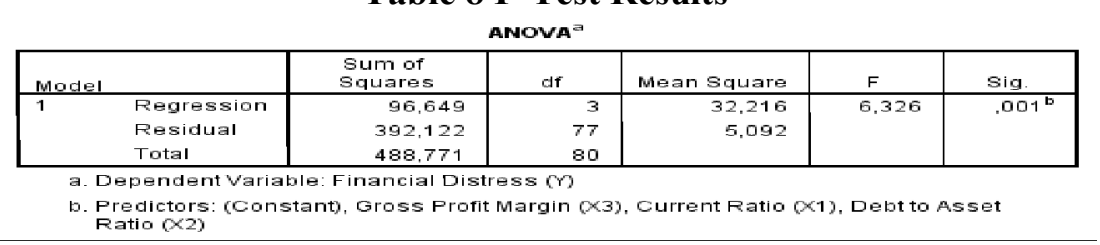

Source: Results of data processing for SPSS V21

Based on table 8 , the results of the SPSS version 21 test above the $F$ test results show that the calculated $\mathrm{F}$ value is greater than the $\mathrm{F}$ table value, namely $6.326>2.72$ and the significance value is smaller than $0.05(0.001<0.05)$. it means that all $\mathrm{CR}$, DAR and GPM variables simultaneously influence the Financial Distress variable.

\section{Coefficient of Determination (R2)}

Table 9 Results of the Coefficient of Determination (R2)

\begin{tabular}{|c|c|c|c|c|c|}
\hline \multicolumn{6}{|c|}{ Model Summary ${ }^{b}$} \\
\hline Model & $\mathrm{F}$ & R Square & $\begin{array}{l}\text { Adjusted R } \\
\text { Square }\end{array}$ & $\begin{array}{l}\text { Std. Error of } \\
\text { the Estimate }\end{array}$ & $\begin{array}{l}\text { Durbin- } \\
\text { Watson }\end{array}$ \\
\hline 1 & $.445^{\mathrm{a}}$ & 198 & 166 & 2,25665 & 1,853 \\
\hline \multicolumn{6}{|c|}{$\begin{array}{l}\text { a. Predictors: (Constant), Gross Profit Margin (X3), Current Ratio }(\times 1) \text {, Debt to } \\
\text { Asset Ratio }(\times 2)\end{array}$} \\
\hline \multicolumn{6}{|c|}{ ๖. Dependent Variable: Financial Distress $(r)$} \\
\hline
\end{tabular}

Source: Results of data processing for SPSS V21

Based on table 9 above, the Financial Distress variable is influenced by all CR, DAR and GPM variables by $16.6 \%$, the remaining $83.4 \%$ is influenced by other variables outside of this study.

\section{Discussion of the moderating hypothesis results Model 1}

$\mathrm{Y}=\mathrm{a} 1+\mathrm{b} 1 \mathrm{x} 1$ (Current Ratio)

$\mathrm{Y}=\mathrm{a} 1+\mathrm{b} 1 \mathrm{x} 1+\mathrm{b} 2 \mathrm{Z}($ Stock price)

$\mathrm{Y}=\mathrm{a} 1+\mathrm{b} 1 \mathrm{x} 1+\mathrm{b} 2 \mathrm{ZX}($ Stock price $)+\mathrm{b} 3 \times 1 * \mathrm{Z}$

a. If equation (2) and (3) are not significantly different or $b 3=0$ (not significant); $b 2 \neq 0$ (significant) then $\mathrm{Z}$ is not a moderator variable.

b. If equation (1) and (2) are not different but different from equation (3), b2 = 0 (not significant); b3 $\neq 0$ (significant) then $\mathrm{Z}$ is the pure moderator variable.

c. If equations (1), (2) and (3) are all significant, $\mathrm{b} 2 \neq 0$ (significant); $\mathrm{b} 3 \neq 0$ (significant) then $\mathrm{Z}$ is a quasi moderator variable.

\section{Hypothesis results model 1}

Hypothesis: Stock Prices moderate the effect of the Current Ratio on Financial Distress

Table 10 Regression Results for Model 1

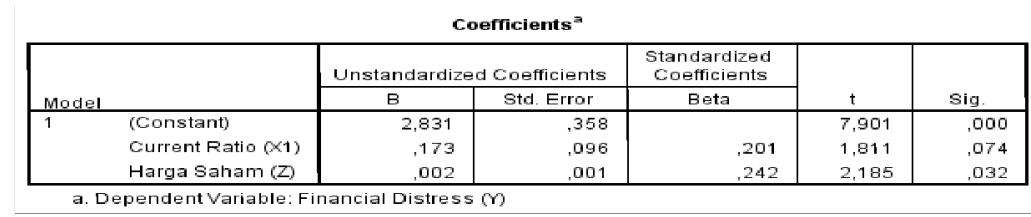

Source: Results of data processing for SPSS V21 
Table 11. MRA1 results

Coefficients $^{\mathrm{a}}$

\begin{tabular}{|c|c|c|c|c|c|c|}
\hline \multirow[b]{2}{*}{ Model } & & \multicolumn{2}{|c|}{ Unstandardized Coefficients } & \multirow{2}{*}{$\begin{array}{c}\begin{array}{c}\text { Standardized } \\
\text { Coefficients }\end{array} \\
\text { Beta }\end{array}$} & \multirow[b]{2}{*}{$t$} & \multirow[b]{2}{*}{ Sig. } \\
\hline & & $B$ & Std. Error & & & \\
\hline \multirow[t]{4}{*}{1} & (Constant) & 3,270 & .365 & & 8,972 & .000 \\
\hline & Current Ratio (X1) & 021 & ,102 &, 024 & 207 & 837 \\
\hline & Harga Saham (Z) &,- 001 & 001 &,- 200 & $-1,164$ & 248 \\
\hline & MRA1 & ,001 &, 000 & 615 & 3,239 &, 002 \\
\hline
\end{tabular}

Source: Results of data processing for SPSS V21

From the two tables in model 1 above, the results of the effect of Stock Price $(Z)$ on Financial Distress (Y) on the first output (significant) are obtained because of the sig. $0.032<0.05$ and the interaction effect of MRA 1 (Share Price * CR) on the second output is significant because of the sig. $0.002<0.05$, it can be stated that in model 1 the Stock Price $(\mathrm{Z})$ is a Moderator variable.

\section{Model 2}

$\mathrm{Y}=\mathrm{a} 2+\mathrm{b} 1 \times 2(\mathrm{DAR})$

$\mathrm{Y}=\mathrm{a} 2+\mathrm{b} 1 \times 2+\mathrm{b} 2 \mathrm{Z}$ (Stock Price)

$\mathrm{Y}=\mathrm{a} 2+\mathrm{b} 1 \mathrm{x} 2+\mathrm{b} 2 \mathrm{ZX}($ Stock Price $)+\mathrm{b} 3 \times 2 * \mathrm{Z}$

a. If equation (2) and (3) are not significantly different or $b 3=0$ (not significant); $b 2 \neq 0$ (significant) then $\mathrm{Z}$ is not a moderator variable

b. If equation (1) and (2) are not different but different from equation (3), b2 = 0 (not significant); b3 $\neq 0$ (significant) then $\mathrm{Z}$ is the pure moderator variable

c. If equations (1), (2) and ( 3 ) are all significant, $\mathrm{b} 2 \neq 0$ (significant); $\mathrm{b} 3 \neq 0$ (significant) then $\mathrm{Z}$ is a quasi moderator variable

\section{Results of the hypothesis model 2}

Hypothesis: Stock Prices moderate the impact of Debt To Asset Ratio (DAR) on Financial Distress

\section{Table 12. Regression Results for Model 1}

\begin{tabular}{|c|c|c|c|c|c|c|}
\hline \multicolumn{7}{|c|}{ Coefficients $^{a}$} \\
\hline \multirow[b]{2}{*}{ Model } & & \multicolumn{2}{|c|}{ Unstandardized Coefficients } & \multirow{2}{*}{$\begin{array}{c}\text { Standardized } \\
\text { Coefficients }\end{array}$} & \multirow[b]{2}{*}{$t$} & \multirow[b]{2}{*}{ Sig. } \\
\hline & & $\mathrm{B}$ & Std. Error & & & \\
\hline 1 & (Constant) & 4,824 & 408 & & 11,817 &, 000 \\
\hline & Debt to Asset Ratio ( $\times 2$ ) & $-4,925$ & 976 &,- 481 & $-5,047$ &, 000 \\
\hline & Harga Saham ( $Z$ ) & 003 & 001 & 392 & 4,106 &, 000 \\
\hline
\end{tabular}

a. Dependent Variable: Financial Distress $(n$

Source: Results of data processing for SPSS V21

Table 13. MRA 2 Results

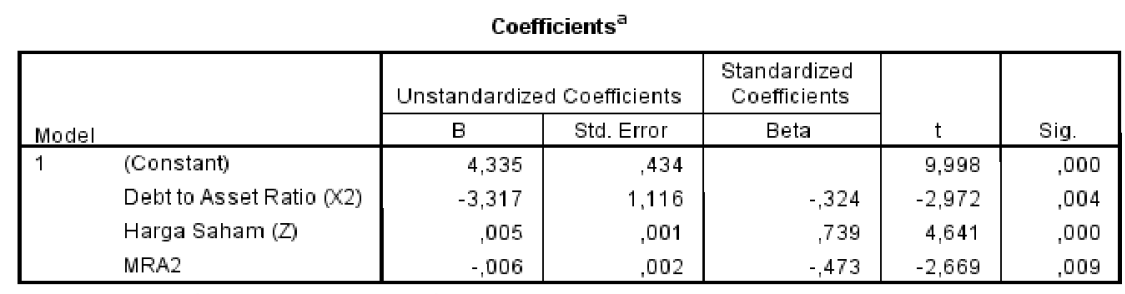

a. Dependent Variable: Financial Distress $(r)$

Source: Results of data processing for SPSS V21

From the two tables in model 2 above, the results of the effect of Stock Price (Z) on Financial Distress (Y) on the first output (significant) are obtained because of the sig. $0.00<0.05$ and the interaction effect of MRA2 (Stock Price * DAR) on the second output is significant because of the sig. $0.009<0.05$, it can be stated that in model 2 the Stock Price $(\mathrm{Z})$ is a Moderator. 


\section{Model 3}

$\mathrm{Y}=\mathrm{a} 3+\mathrm{b} 1 \times 3(\mathrm{GPM})$

$\mathrm{Y}=\mathrm{a} 3+\mathrm{b} 1 \times 3+\mathrm{b} 2 \mathrm{Z}$ (Stock Price)

$\mathrm{Y}=\mathrm{a} 3+\mathrm{b} 1 \times 3+\mathrm{b} 2 \mathrm{ZX}($ Stock Price $)+\mathrm{b} 3 \times 3 * \mathrm{Z}$

a. If equation (2) and (3) are not significantly different or $b 3=0$ (not significant); $b 2 \neq 0$ (significant) then $\mathrm{Z}$ is not a moderator variable

b. If equation (1) and (2) are not different but different from equation (3), b2 = 0 (not significant); b3 $\neq 0$ (significant) then $\mathrm{Z}$ is the pure moderator variable

c. If equations (1), (2) and ( 3 ) are all significant, $\mathrm{b} 2 \neq 0$ (significant); $\mathrm{b} 3 \neq 0$ (significant) then $\mathrm{Z}$ is a quasi moderator variable

\section{Results of the hypothesis model 3}

Hypothesis: Stock Price moderates the effect of Gross Profit Margin (GPM) on Financial Distress

Table 14. Regression Results Model 3

\begin{tabular}{|c|c|c|c|c|c|c|}
\hline \multicolumn{7}{|c|}{ Coefficients $^{a}$} \\
\hline \multirow[b]{2}{*}{ Madel } & & \multicolumn{2}{|c|}{ Unstandardized Coefficients } & \multirow{2}{*}{$\begin{array}{c}\begin{array}{c}\text { Standardized } \\
\text { Coefficients }\end{array} \\
\text { Beta }\end{array}$} & \multirow[b]{2}{*}{$t$} & \multirow[b]{2}{*}{ Sig. } \\
\hline & & $B$ & Std. Error & & & \\
\hline 1 & (Constant) & 2,424 & 487 & & 4,982 &, 000 \\
\hline & Gross Profit Margin $(\times 3)$ & 1,474 &, 731 & .216 & 2,017 &, 047 \\
\hline & Harga Saham $(Z)$ &, 002 & 001 & 340 & 3,178 &, 002 \\
\hline
\end{tabular}

Source: Results of data processing for SPSS V21

Table 15. MRA 3 Results

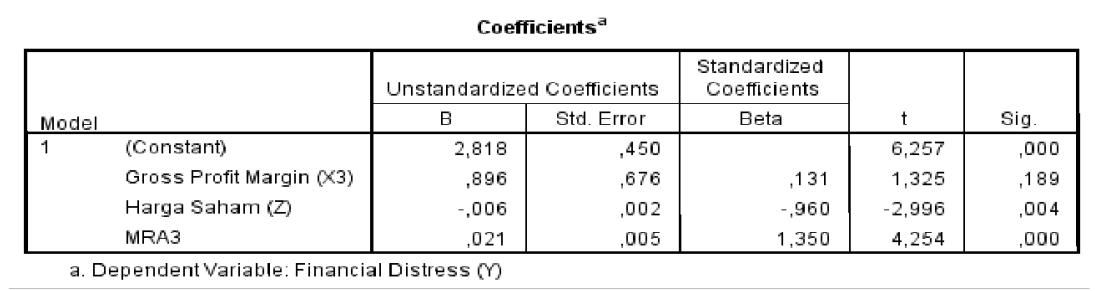

Source: Results of data processing for SPSS V21

From the two tables in model 3 above, the results of the effect of stock price $(Z)$ on financial distress (Y) on the first output (significant) are obtained because of the sig. $0.002<0.05$ and the interaction effect of MRA3 (Stock Price * GPM) on the second output is significant because of the sig. $0.00<0.05$, it can be stated that in model 3 The Stock Price $(Z)$ is a Moderator variable.

IV. CONCLUSION

Based on the discussion of the research results that have been described, it can be concluded that:

1. Partially Current Ratio has no significant effect on Financial Distress

2. Partially Debt To Asset Ratio has no significant effect on Financial Distress

3. Partially Gross Profit Margin has a significant effect on Financial Distress

4. Current Ratio, Debt To Asset Ratio and Gross Profit Margin simultaneously have a significant effect on Financial Distress in retail companies listed on the Southeast Asian Stock Exchange

5. Share Prices moderate Current Ratio (CR) to Financial Distress

6. Share Prices moderate the Debt to Asset Ratio (DAR) against Financial Distress

Share Prices moderate Gross Profit Margin (GPM) against Financial Distress

\section{REFERENCE}

[1] Justin, Amy, Grant dan Robert, (2020). Predicting Nursing Home Financial Distress Using the Altman Z-Score. The Journal of Health Care Organization, Provision, and Financing Volume 57: 1-9 (C) The Author(s) 2020 
Article reuse guidelines: sagepub.com/journals-permissions

[2] Marota, R., Alipudin, A., Maiyarash, A. (2018). Pengaruh Debt To Assets Ratio (DAR), Current Ratio (CR) Dan Corporate Governance DalamMemprediksi Financial Distress Pada Perusahaan BumnSektor Non Keuangan Yang Terdaftar Di Bursa Efek Indonesia. JIAFE ( Jurnal Ilmiah Akuntansi Fakultas Ekonomi) Vol. 4 No. 2, Des.2018, Hal. 249-266 https://journal.unpak.ac.id/index.php/jiafe P-ISSN: 2502-3020, E-ISSN: 25024159

[3] Septine, C., Manurung M. A. H., Hutahayan,B., (2020). Analysis of The Effect of Financial Ratios to Probability Default of Indonesia's Coal Mining Company. Journal of applied finance \& banking, vol. 10, No.5, 2020, 167 179 .ISSN : 1792-6580 (Print Version), 1792-6559 (Online)

[4] Zakiyuddien, (2018). The Ability Of Profitability To Moderate The Effect Of Liquidity, Leverage And Operating Capacity On Financial Distress (Empirical Study On Retail Companies Registered On Idx 2012- 2017). Prosiding Business And Economics Conference In Utilizing Of Modern Technology. Issn 2622 - 9404

[5] Rodríguez-Rad, Carlos J., Francisco Javier Rondan-Cataluña.(2017). A longitudinal study of franchisor failure according to Altman's Z model.Journal of Business-to-Business Marketing 24(2):1-14, October 2017DOI: $10.1080 / 1051712 X .2018 .1381416$

[6] Noviandri, Tio. (2014). PerananAnalisisRasioKeuanganDalamMemprediksiKondisi Financial Distress Perusahaan SektorPerdagangan. JurnalllmuManajemen. JurusanManajemen, FakultasEkonomi, UniversitasNegeri Surabaya, Volume 2 Nomor 4 Oktober 2014

[7] Indriani , Rina., Thamrin ,Hakiman (2020). Model Of Bankruptcy Prediction Services Company Sector Retail In Indonesia Stock Exchange (Study Case Period 2015 - 2017). Master of Management, Mercubuana University, Jakarta, Indonesia Volume 1, Issue 2, Febuary 2020 E-ISSN : 2715-4203, P-ISSN : 2715-419X Available Online: https://dinastipub.org/DIJDBM

[8] Sayari, Naz ., Mugan, Bisa S., (2016) Industry specific financial distress modeling. Winston Salem, NC 27106, USA b Izmir University of Economics, Faculty of Business, SakaryaCaddesi No: 156, 35330 Balcova, Izmir, Turkey Received 22 July 2015; accepted 11 March 2016. BRQ Bus. Res. Q. 2016, http://dx.doi.org/10.1016/j.brq.2016.03.003

[9] Wawo, Andi., Nirwana (2020). Pengaruh Financial Distress Terhadap Harga Saham, Akuntansi Peradaban : Vol. VI No. 1 Juni 2020, ISSN: 2442-3017 (Print) Issn: 2597-9116 (Online)

[10] Mahruzala , Khaddafi, M. (2020). The Influence of Gross Profit Margin, Operating Profit Margin and Net Profit Margin on the Stock Price of Consumer Good Industry in the Indonesia Stock Exchange on 2012-2014, International Journal of Business, Economics and Social Development Vol. 1, No. 3, pp. 2020. e-ISSN 27221156 p-ISSN 27722-1164, https://journal.rescollacomm.com/index.php/ijbesd/index

[11] Pratama, Aditya., Erawati, Teguh. (2014).Pengaruh Current Ratio, Debt To Equity Ratio, Return On Equity, Net Profit Margin Dan Earning Per Share TerhadapHargaSaham (Study KasusPada Perusahaan Manufaktur Yang Terdaftar Di Bursa Efek Indonesia Periode 2008-2011). Jurnal Akuntansi. VOL.2 NO.1 JUNI 2014

[12] Damar, H., Farouk, U., Winarto. ( 2015). Analysis Of The Effect Of Financial Leverage And Liquidity Towards Stock Value And Profitability As The Intervening Variable In Trading Companies Listed At Indonesia Stock Exchange 2010-2014. Business Administration Department, Semarang State Polytechnic. JOBS (JurnalOf Business Studies) ISSN: 2461-0704 \& e-ISSN: 2476-8790

[13] Andira, Ratna.(2018). Pengaruh Kinerja Keuangan Terhadap Harga Saham Perusahaan Retail Yang Terdaftar Di Bursa Efek Indonesia (BEI). Program Studi: Manajemen Sekolah Tinggi Ilmu Ekonomi Indonesia (STIESIA). Surabaya 2018

[14] Jessy, Funny, Cindy, Evelyn danJeanny, (2020) .Pengaruh CR (Current Ratio), DER (Debt to Equity Ratio), EPS (Earning Per Share) dan Financial Distress (Altman Score) Terhadap Harga Saham Pada Perusahaan Sektor Industri Dasar dan Kimia Yang Terdaftar Di Bursa Efek Indonesia . RISET \& JURNAL AKUNTANSI Volume 4 Nomor 1, Februari 2020 https://doi.org/10.33395/owner.v4i1.176 e -ISSN : 2548-9224 p-ISSN : 2548-7507 